\title{
A tasteless lesion
}

\author{
J.A. Feldman, MD; S.L. Galetta, MD; R.R. Miselis, VMD, PhD; \\ A.C. Rosenquist, PhD; and B.M. Ances, MD, PhD
}

A 45-year-old restaurant owner noted loss of taste over his entire left tongue during a twoweek time period. Neurologic exam was otherwise normal including facial strength. Brain MRI revealed an enhancing lesion of the left dorsal pons (figure, $\mathrm{A}$ and $\mathrm{B})$. The patient subsequently developed coordination difficulties and double vision. Repeat MRI confirmed a left superior cerebellar and a new frontal white matter lesion consistent with multiple sclerosis.

The anatomy of the secondary projection fibers conveying the sensation of taste in humans remains poorly understood. ${ }^{1} \mathrm{Re}-$ cent mapping studies in monkeys suggest that the second order neuron projections from the nucleus of the solitary tract pass through the dorsolateral pons before ascending as the central tegmental tract. ${ }^{2}$ The lesion in our patient is just above the nucleus of the solitary tract and lies in the location of the second order neurons that project to the thalamus for taste.

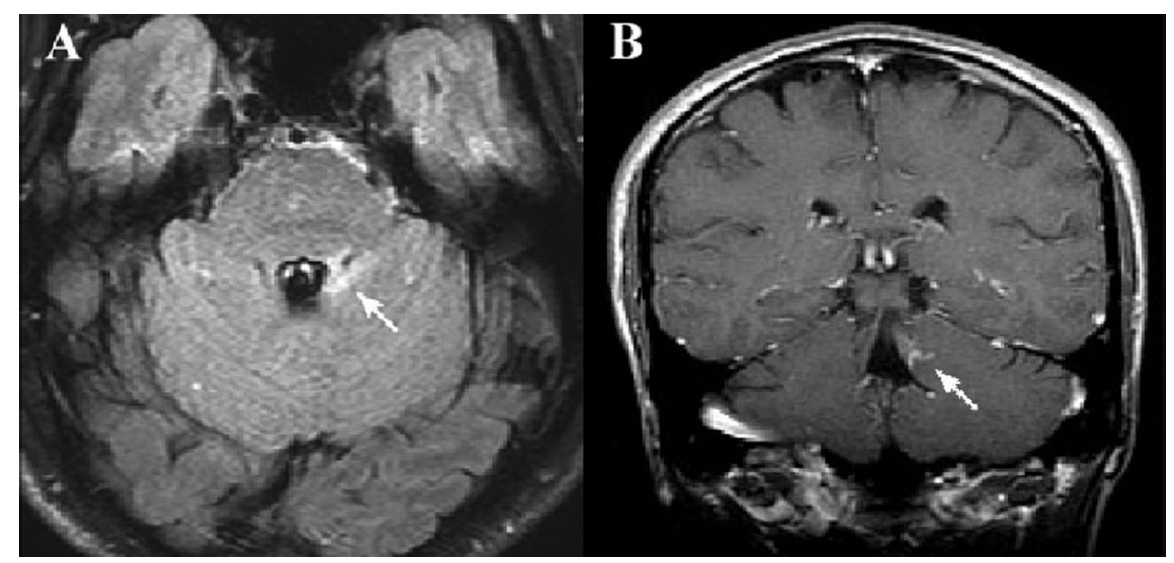

We conclude that the ascending taste fibers from the nucleus solitarius travel within the dorsolateral pons just medial to the superior cerebellar peduncle. A lesion in this location may produce this isolated deficit.

\section{References}

1. Combarros O, Sanchez-Juan P, Berciano J, et al. Hemiageusia from an ipsilateral MS plaque at the midpontine tegmentum. J Neurol Neurosurg Psychiatry 2000;68:796.

2. Paxinos G, ed. Human nervous system, 1st ed. San Diego: Academic Press Inc.; 1990: 852 .

Figure. (A) Axial fluid level attenuation recovery MRI above the level of the nucleus of the solitary tract and (B) T1 postcontrast coronal at the pontomesencephalon. In both images, arrow shows demyelinating lesion.

From the Departments of Neurology (J.A.F., S.L.G.), Veterinary Medicine (R.R.M.), and Neuroscience (A.C.R.), University of Pennsylvania, Philadelphia; and the Departments of Neuroscience and Radiology (B.M.A.), University of California San Diego. Disclosure: The authors report no conflicts of interest.

Address correspondence and reprint requests to Dr. Jessica A. Feldman, Department of Neurology, 3 West Gates, Hospital of the University of Pennsylvania, 3400 Spruce Street, Philadelphia, PA; e-mail: jfeldma2000@hotmail.com 


\title{
Neurology
}

\author{
A tasteless lesion \\ J. A. Feldman, S. L. Galetta, R. R. Miselis, et al. \\ Neurology 2006;67;E1 \\ DOI 10.1212/01.wnl.0000223845.60960.d7
}

\section{This information is current as of July 10, 2006}

\section{Updated Information \&} Services

References

Permissions \& Licensing

Reprints including high resolution figures, can be found at: http://n.neurology.org/content/67/1/E1.full

This article cites 1 articles, 1 of which you can access for free at: http://n.neurology.org/content/67/1/E1.full\#ref-list-1

Information about reproducing this article in parts (figures,tables) or in its entirety can be found online at:

http://www.neurology.org/about/about_the_journal\#permissions

Information about ordering reprints can be found online: http://n.neurology.org/subscribers/advertise

Neurology ${ }^{\circledR}$ is the official journal of the American Academy of Neurology. Published continuously since 1951, it is now a weekly with 48 issues per year. Copyright . All rights reserved. Print ISSN: 0028-3878. Online ISSN: 1526-632X.

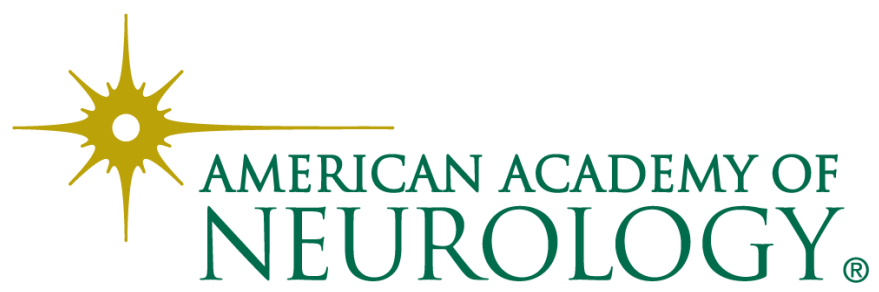

